DOI: $10.24193 /$ tras.64E.7

Published First Online: 10/28/2021

\section{MUNICIPAL FRAGMENTATION \\ AND LOCAL FINANCIAL CONDITION}

\section{HyungGun PARK}

\section{HyungGun PARK}

Ph.D., Assistant Professor, Department of Public Administration, Myongji University, Seoul, South Korea

Tel.: 0082-2-300-0674

E-mail: hyunggunpark@mju.ac.kr ORCID ID: 0000-0002-9046-1286

\section{Abstract}

A sizeable literature investigates how intergovernmental competition affects various fiscal outcomes in a fragmented local landscape. However, it remains untested how the fragmentation affects the outcomes simultaneously. This study addresses the issue by condensing individual outcomes into a multifaceted concept of financial condition. Utilizing a pooled cross-sectional time-series approach on the metropolitan statistical areas in the U.S between 1972 and 2017, this study tests how financial condition of municipalities varies by competition among them. The finding exhibit adverse effects on their financial condition when a greater number of municipalities is identified.

Keywords: government fragmentation, intergovernmental competition, financial condition, factor analysis, panel-corrected standard error pooled regression. 


\section{Introduction}

Local governments decide which and how much services to produce with different tax authorities, and citizens shop for packages of taxes and services from one jurisdiction to another. Numerous governments satisfy citizens' heterogeneous service demands more effectively than a few, as a larger number of such local authorities provide distinctive tax and service packages for the citizens (Schneider, 1989; Tiebout, 1956). As the citizen's migration indicates relocation of wealth and potential for economic development, the fragmented local landscape, composed of numerous municipalities, is often described as the rivalry among local governments (Boyne, 1992; Eberts and Gronberg, 1988; Ostrom and Ostrom, 1965). Citizens may compare the tax and service packages across jurisdictions, signaling governments to provide popularly appealing packages - more services and lower tax rates. Sufficient public service benefit and zero tax are infeasible, but local governments may want to attract citizens beyond their capacity to provide unique packages, intensifying competitive interlocal relationships further. Competition pressures local governments to manage the allocation of limited public resources, to lower the service production cost, and reduce the size of their organizations, thereby achieving greater efficiency to survive on the competitive market of public goods and services (Brennan and Buchanan, 1980).

Though municipal fragmentation is associated with efficiency gains, the actual number of municipalities demonstrates the opposite story, since their number should have increased if greater fragmentation is equivalent to greater gains. The number of cities and townships in the U.S. has marginally changed, with a few cases of incorporation and dissolution, as the Bureau of Census reports 35,508 subcounty general-purpose governments in 1972 and 35,599 in 2017. The trends indicate that the benefits of municipal fragmentation may be offset by some negative factors. Such gap between theories and reality is understood differently depending on the subject of interest, which varies across government financial outcomes, urban sprawl, unequal service provision, and income segregation (Carruthers and Ulfarsson, 2002; Hill, 1974; Lyons, Lowery and DeHoog, 1992; McGuire, 1991).

This study utilizes a factor score of municipal financial condition to incorporate diverse fiscal outcomes into a single broad concept. The financial condition is defined as the ability, willingness, and amount of resources of a municipality to meet its financial and service obligations (Berne, 1992; Hendrick, 2004, 2011; GASB, 2009; Groves, Nollenberger and Valente, 2003; Ladd and Yinger, 1989). The financial condition is a complex and multifaceted concept understood with several measures, such as solvency types across different time spans, the difference between expenditure needs and the revenue-raising capacity, and demographic and environmental factors associated with government performance (Chernick and Reschovsky, 2001; Hendrick, 2004; Justice and Scorsone, 2013; Ladd and Yinger, 1989). In order to encompass various financial indicators that define different aspects of the fiscal outcomes, this study utilizes factor analysis to measure the concept of the financial condition comprehensively. 
The estimation result of pooled cross-sectional time series regression with panel-corrected standard error using U.S metropolitan statistical area (MSA) data from 1972 to 2017 shows that fragmentation declines the financial condition of municipalities. Findings of this study contribute to the literature of intergovernmental relationships at the regional level and fiscal outcomes fragmentation. By using the concept of financial condition, this study tests different fiscal outcomes that are not directly comparable, and diagnoses whether municipal fragmentation is beneficial beyond separate fiscal outcomes.

In the following section, the theoretical foundation of municipal government fragmentation and empirical studies of determinants of the local financial condition are introduced. The next section suggests theoretical bases about how municipal fragmentation affects the financial condition of cities and townships negatively. Finally, the findings and implications of this study are discussed.

\section{Literature review}

\subsection{Fiscal outcomes of government fragmentation}

Scholars speculate the opposite effects of government fragmentation on two types of efficiency: allocative efficiency, that stands for responsiveness to citizen preference, and technical efficiency, that represents the production of services with lower inputs (Boyne, 1996; Dowding and Mergoupis, 2003; Goodman, 2019). First, it is proposed that fragmentation increases both efficiencies. Citizens vote with their feet for a preferred set of services at an affordable tax rate if there is no restriction in relocation, and the citizens have full information on service provision in all jurisdictions. An increase in allocative efficiency reflects several competing governments providing assorted services from which citizens can choose what they want and can pay. A decrease in the level of government spending reflects that public resources are optimally utilized, and wasted resources are minimal (Brennan and Buchanan, 1980; Schneider, 1989).

Brennan and Buchanan (1980) suggest that government size without competition tends to grow, due to the absence of a benchmark of performance. Bureaucrats benefit from the larger budget as it preserves their political power. The bureaucrats' budget-maximizing effort derives from asymmetric information of the actual cost of service production (Niskanen, 1971; Schneider, 1989). The cost information is roughly available when citizens can compare tax amounts of a certain quality of services from other governments. Thus, the fragmentation enables taxpayers to approximate the cost and pressure their governments to lower tax rates by comparing neighboring jurisdictions' performance (Besley and Case, 1995; Breton, 1991).

Oppositely, some studies posit that the municipal fragmentation impedes both the technical efficiency and allocative efficiency of governments as an intensive competition raises transaction costs across governments (ACIR, 1974; Carruthers and Ulfarsson, 2002). Since the types of government services are finite and political 
authorities tend to favor the popular interest, governments tend to provide some duplicated services, thereby limiting public choice. Also, it is less costly for a single government to specialize in the production of some services than when several governments produce the same services separately; thus, some inputs can be saved when producing different services that require similar inputs (Boyne, 1992; Panzar and Willig, 1981). The lesser competition derived from the defragmented governments allows governments to run more efficiently by reducing the number of governments that could provide services separately.

Second, some scholars focus on fiscal equity of service distribution to citizens. Oates (1972) argues that some services are provided at suboptimal level because some services with high spillover effects may benefit competing governments unless enforced to pay for the benefit. The presence of spillover in public services makes a local government levy on less stable revenue sources rather than on property taxes (Wildasin, 1989).

Also, as local governments vary by the capacity for public service provision, municipal fragmentation often leads to unequal access to public services (Boyne, 1992; McGuire, 1991; Oakerson, 1999). McGuire (1991) suggests that the threat of migration makes the government's levy taxes on the affluent lower than an optimal rate for sustainable service provision when all local governments attract wealthy households with tax cuts. Thus, the budget deficit derived from revenue-expenditure imbalance reduces types and levels of existing services or burdens other taxpayers. Hoyt (1991) proposes that a government's response to tax rate changes in a neighboring jurisdiction results in changes in service levels that may not correspond to the actual demand of citizens.

Third, the fragmentation also facilitates racial and income segregation. Segregation may result from a governments' exercise of power to exclude and to particularize services through zoning and land use control (Hill, 1974; Lyons, Lowery and DeHoog, 1992). However, the affluent are more likely capable of relocating when segregation causes these issues. This implies that the poor residents have no other choice but to remain in a jurisdiction, while the affluent households migrate to jurisdictions with better services at the higher tax rates with exclusive benefits of public goods and services (Lowey, 2000).

Last, it is argued that fragmentation makes urban sprawl hard to control. Divided land-use authority across several jurisdictions allows local governments to exercise zoning within a jurisdictional boundary. The uncooperative development reaches to areas with a small population, resulting in operating deficits for service provision (Carruthers and Ulfarsson, 2002).

\subsection{Determinants of local financial condition}

Several studies investigate the factors that determine local governments' ability to meet diverse service needs. First, local demographic composition matters. Jacob and Hendrick (2013) provide examples of spending needs, such as crime levels for police 
protection service, age of infrastructure for fire service, capital spending, building inspection, the income level of citizens, employment status, and cost of public health and welfare services. Also, they propose that population growth and economic development increase government spending in general. Groves, Nollenberger and Valente (2003) suggest that some demographic factors directly or indirectly affect local financial condition, such as population density, personal income per capita, property value, homeownership, business activity, number of jobs in the community, vulnerable populations, poverty rate, vacancy rate, unemployment rate, mandated expenditure proportion, and the higher chance of experiencing natural disasters in certain locations.

Second, composition of the primary source of the municipality's revenue demonstrates the capacity to maintain a countercyclical fiscal policy against economic fluctuation. Different governments have different compositions of revenue sources, where some sources are more volatile and income-elastic as they tend to follow macro-economic conditions, and other sources vary by the growth of local government and stability (Carroll and Goodman, 2013). It is suggested that the balance of major revenue categories, such as property tax, sales tax, intergovernmental transfers, and user fees and charges, is crucial for local governments to fiscally sustain against external events and provide more stability and flexibility in financial management, thereby achieving better fiscal outcomes (Suyderhoud, 1994). Shamsub and Akoto (2004) demonstrate that local revenue diversification increases financial condition measured by local tax efforts, implying that states that give greater authority to local governments to collect revenues from diverse sources experience less fiscal stress.

Relatedly, as citizens expect governments to fulfill financial and service liability consistently, economic cycles (or macroeconomic conditions) are crucial for the fiscal status of local governments. Gist (1988) demonstrates that local financial condition is primarily due to national economic performance. Gist finds that the financial condition index of Virginia's local governments for eight fiscal years was negatively affected by unemployment levels, suggesting that structural employment widens fiscal capacity gaps across cities. For the Commonwealth of Virginia, fiscal stress in the 1980s was due to the national recession, relatively slow growth in household income compared to increases in interest rates, and reduced federal aids (Badu and $\mathrm{Li}$, 1994). Similarly, McGranahan (1999) finds that changes in business cycles, measured as state unemployment rates, is a leading factor of local fiscal stress. Peters (1980) and Gold (1995) both show that fiscal stress in the public sector mainly results from stagnant growth and recession.

Last, the intergovernmental relationship is frequently stressed, but rarely studied empirically as a determinant. Focusing on Wisconsin, New York, and California, Chernick and Reschovsky (2001) find that state aid tends to be allocated to the wealthy suburban areas rather than serving to support central cities' struggles against slow growth in fiscal capacity. Chernick and Reschovsky also find that the central cities' welfare reforms eroded overall revenue sources as states decreased the share of funding allocated to the cities. Maher and Deller (2011) demonstrate that the stringency 
of state fiscal rules has diverging effects on financial condition indicators. They show that the more stringent state fiscal rules tend to diminish the local financial condition, specifically limiting local own-source revenues and general expenditures. Honadle (2013) discusses side effects of each jurisdiction acting in its own purposes. For example, a municipality's pursuit of relocating business will create jobs and provide revenue sources from property and merchandise transactions, which pressures overlying school districts to increase their budgets due to the increase in the student population as a result of the business relocation. Also, debts of a political jurisdiction may damage the financial condition of overall overlapping jurisdictions. A school district's bond issuance over local properties influences the city's capacity to support its debt, thereby damaging the city's credit ratings and incurring higher spending on debt service.

Various factors are tested to see how they are linked to changes in the local financial condition. While a few studies stress the importance of neighboring jurisdictions' fiscal decisions, the relationship between interlocal relationships and the financial condition is left untested except for a few research studies. Morgan and Mareschal (1999) test the effects of interlocal competition on the local financial condition, but their model focuses on a single government outcome without considering the multi-dimensional aspects of the financial condition. Honadle (2013) argues on diverse patterns of how other local governments influence a government's fiscal environment and fiscal distress management, but her claims remain untested with a large number of observations.

\section{Hypotheses}

The fragmentation of municipal governments is expected to have negative impacts on their financial condition for three reasons. First, the presence of many municipalities entails excessive competition, eroding the governments' long-term potentials essential to meet financial and service demands. The purpose of intergovernmental competition is to attract citizens (ACIR, 1991), which are regarded as mobile wealth that contributes to a municipality's finance. The migration of wealth becomes economic gains for some governments that relocate the citizens, and it is the loss of wealth for the place they are leaving (McGuire, 1991). Many service suppliers in the local public service market meet demands of diverse service preferences and capacity to pay for the services, but citizens are always incentivized to vote with their feet to other jurisdictions with more services at the lower tax rates.

In order not to lose from this competition, municipalities, namely those with the lower fiscal capacity, have two options that result in further declines in the financial condition. One is that the small municipalities may provide a lower level of service that promises fiscal soundness. However, the mediocre service level leads to the loss of citizens who seek for more services at the lower tax rates. Once citizens and businesses leave, the municipalities lose revenue bases and have to reduce service levels 
to keep their fiscal condition robust. Another option is that the municipalities may provide constant level of services at the lower tax rate. However, such fiscal policy cannot be sustained in the long run unless unearned external funding is promised. If fiscally less capable governments provide a competitive tax and service package similar to that of the more capable municipalities, either by providing more services or by reducing tax, they eventually run a deficit or issue debts that defer the current deficit (Bailey, Rom and Taylor, 2004; Fischel, 1981; Volden, 2002). Therefore, fragmentation worsens the local governments' ability to meet financial and service demands.

Second, the competition among municipalities is similar to the competition among firms in the private market, but a major difference exists. In the private sector, a market is balanced by replacing less competitive firms with more capable ones. However, fiscally struggling governments remain in the public service market as governments occasionally dissolve. The fiscally unsound municipalities that have lost from the competition persist, hampering the efficient resource allocation of the entire market of public goods and services as they do not contribute to service differentiation (Alesina, Baqir and Hoxby, 2004). Some processes, equivalent to the free entry and exit of firms in the public sector, such as city-county consolidation, city-city merger, and annexation, do not result in fiscal advancement. Some efficiency gain from the scale economy may be achieved through unification, but at the same time some negative outcomes from maintaining fiscally less capable municipalities should be considered, as the boundary changes of local governments formulate one sizeable economy without replacing fiscally unsound ones.

Third, non-competitive interaction among municipalities is costly. Collaborative partnership may be an alternative way to provide services as local governments can provide some services commonly demanded across several jurisdictions. However, the efficiency gains from partnerships are marginal due to the cost of coordination. It is unclear who is accountable for service provision if the partnership fails to meet citizen demands, and continuing expenses for monitoring and quality control in compliance with the needs of the member jurisdictions are required (Williamson, 1987). Also, a partnership demands additional costs to incentivize governments in exclusive relationships to participate in a collective service provision process, and to enforce the participants to contribute to shared interests continuously (Carr and Hawkins, 2013; Feiock and Scholz, 2009). The participants vary by capacity, and some participants contribute more than the rest, who may take unearned benefits. When relative contributors see the others as financially constrained free riders that enjoy a collective benefit without contributing to it, commitment issues arise, which incentivizes the contributors to not bear higher costs than their share of benefit (Feiock et al., 2010).

Also, fragmentation encompasses competitive relationships among municipalities. One additional municipality at a local service market may differentiate its service and tax levels with the existing counterparts; thus, the competitive relationship increases as much as the number of municipalities nearby. In such regard, the possible number 
of competitive relationships in the fragmented local landscape increases exponentially when the number of governments increases (Boyne, 1992; Grossman, Pierskalla and Boswell Dean, 2017).

The discussion above generates a set of hypotheses:

- H1: Municipality fragmentation has a negative effect on the municipal financial condition;

- H2: Municipality fragmentation has a nonlinear effect at an increasing rate on the municipal financial condition.

\section{Research design}

This study tests the hypotheses utilizing metropolitan statistical area (MSA) data from State and Local Government Finance, previously known as the U.S. Census of Governments. MSA is selected as the unit of analysis as it is designated based on a substantial population core with adjacent communities having active economic and social integration with the core. Citizen migration across the variety of service and tax packages can be identified in the MSA rather than outside. This study utilizes 348 MSAs from 48 states, between 1972 and 2017, every five years (years that end up with two or seven). MSAs from two states, Alaska and Hawaii, are excluded due to the local revenue structure and economy size that are distinctively different from the rest.

\subsection{Dependent variable}

A municipal government's financial condition as a dependent variable is measured as a factor score of six financial indicators. The extant literature of financial condition measures the concept either with separate financial indicators or with an additive index (Brown, 1993; Gorina, Maher and Joffe, 2018; Maher and Deller, 2011). This is due to the fact that the concept is complex and multifaceted, with individual dimensions which may be directly measurable, but each measure represents limited aspects of the financial condition concept. The index simplifies the multiple dimensions by aggregating evaluative scores of each dimension, but the approach assigns arbitrary weight on individual direct measures, which associates overrepresented and overlooked aspects of the financial condition (Clark, 2015).

Factor analysis simplifies complex social phenomena, condensing multiple direct measures into fewer representative measures (i.e., factors) with minimal loss of information from the original measures (Olkin, 2001). For example, factor analysis is used to measure multifaceted concepts, such as municipal credit quality and leadership (Krueger and Walker, 2010; Park and Rainey, 2008).

Six direct indicators of financial condition ${ }^{1}$ (budget surplus and deficit, capital expenditure, cash and security holding, current operating expenditure, long-term debt

1 Twelve indicators that include the six indicators in this study are also analyzed, but the six indicators represent the concept of financial condition better. Please see Appendix for details. 
outstanding, and own-source revenue over total revenue) are selected based on the extant literature. Each value of the indicators is in 2017 values based on the Consumer Price Index and divided by 10,000 population to control the relative municipality size. The factor analysis generates one factor out of the six indicators for each year, identifying individual factor loadings that are correlation coefficients between each indicator and the factor. The factor score is calculated as each municipality's financial indicators multiplied by corresponding factor loadings for each year. The financial condition scores for each year are normally distributed with a mean of zero and standard deviation of one, and the lower value represents the worse financial condition, and the higher value means the opposite. Finally, individual municipalities' financial condition factor scores are averaged at the MSA level.

\subsection{Independent variables}

The main independent variable of this study is municipal fragmentation, and it is measured as the number of cities and townships in each MSA. Counts of municipalities are computed using two information, Federal Information Processing Standard (FIPS) code and Core-Based Statistical Area (CBSA) code. Census of Government data from the U.S. Census Bureau provides jurisdictional information of local governments via FIPS code. FIPS code demonstrates in which state and county a local government is located. Census also provides FIPS codes of county governments with CBSA codes that delineate boundaries of the metropolitan statistical area from the Office of Management and Budget (OMB). The number of distinctive municipal governments' FIPS codes are aggregated at each CBSA. Squared term of the counts of municipalities is included to capture nonlinear effects of the fragmentation.

Some demographic and financial variables that affect the municipalities' financial condition are controlled. First, the overall population size that represents both service demand and revenue source is included as the natural logarithm total population of municipalities. Second, the elderly population is measured as a percentage of the population over the age of 65 . Third, the non-white population is measured as a total population minus the white population, then divided by the total population. Fourth, the local income level is measured as the median family income. The income information is adjusted based on CPI. These four demographic factors are obtained from the American Community Survey data from the U.S. Census Bureau. Fifth, intergovernmental revenue is measured as the amount of revenue received from other governments divided by the total revenue of a local government. Sixth, the revenue structure of municipal governments is measured as the Hirschman-Herfindahl Index (HHI) of four major revenue categories of local governments, such as property tax, intergovernmental transfer, user fees, and all others (Carroll and Goodman, 2013) 2 .

$2 \mathrm{HHI}$ of revenue diversification is calculated as, where R represents the ratio of one of the four revenue categories over total revenue, $i$ indexes four revenue categories $(\mathrm{N}=4)$. 
Last, the economic recession is measured as the unemployment rate as a result of the recession on the local economy. The estimated unemployment rate for each county is available at the U.S. Bureau of Labor Statistics. These control variables of individual municipalities are average values at the MSA level. Table 1 below shows the concept, measurement, and data source of the variables.

In order to address errors correlated across jurisdiction over multiple years in the pooled time-series data, the variables are estimated using regression with panel-corrected standard errors (Beck and Katz, 1995). Also, to control the unobservable characteristics of the individual public service market, fixed effects of each MSA is controlled by adding dummy variables of individual MSAs (Wooldridge, 2012).

\section{Findings}

Table 2 demonstrates descriptive statistics of variables.

Table 2: Descriptive statistics of variables

\begin{tabular}{lcccccc}
\hline \multicolumn{1}{c}{ Variables } & N & Mean & Median & StDev & Min & Max \\
\hline Financial condition factor score & 3,480 & 0 & 0.074 & 1 & -9.378 & 2.946 \\
\hline Number of municipalities & 3,480 & 6.611 & 4 & 7.193 & 2 & 56 \\
\hline Number of municipalities squared & 3,480 & 95.434 & 22 & 301.631 & 4 & 3,136 \\
\hline Logged population & 3,480 & 33.808 & 22.677 & 35.458 & 10.159 & 325.702 \\
\hline Population over 65 (\%) & 3,480 & 0.123 & 0.121 & 0.035 & 0.022 & 0.348 \\
\hline Non-white population (\%) & 3,480 & 0.145 & 0.107 & 0.117 & 0.004 & 0.588 \\
\hline Median family income & 3,480 & 35,471 & 34,567 & 17,668 & 7,511 & 98,527 \\
Intergovernmental revenue over total revenue (\%) & 3,480 & 0.280 & 0.275 & 0.125 & 0.004 & 0.739 \\
Revenue diversification (\%) & 3,480 & 0.146 & 0.130 & 0.095 & 0.001 & 0.637 \\
Unemployment rate (\%) & 3,480 & 0.061 & 0.059 & 0.020 & 0.018 & 0.140 \\
\hline
\end{tabular}

Source: Author's own work

The factor analysis procedure generates a continuous variable of financial condition score, of which an average value of zero indicates that an MSA's financial condition score above the value represents the fiscally healthier condition of consisting municipalities than the national average each year. The number of municipalities varies by MSA, ranging from 2 to 56 .

The estimation results in Table 3 support the hypotheses. In both models, with (1) and without (2) the squared term of municipality counts, the municipal fragmentation has negative effects on their financial condition consistently. In the model with the nonlinear effect (2), the number of municipalities has negative effects on the financial condition with a considerable nonlinear effect. These patterns indicate that municipal fragmentation worsens their fiscal condition at an increasing rate.

Control variables have similar estimated effects on the fiscal effects as in the existing empirical studies of financial condition. Municipalities' ethnic diversity and revenue 


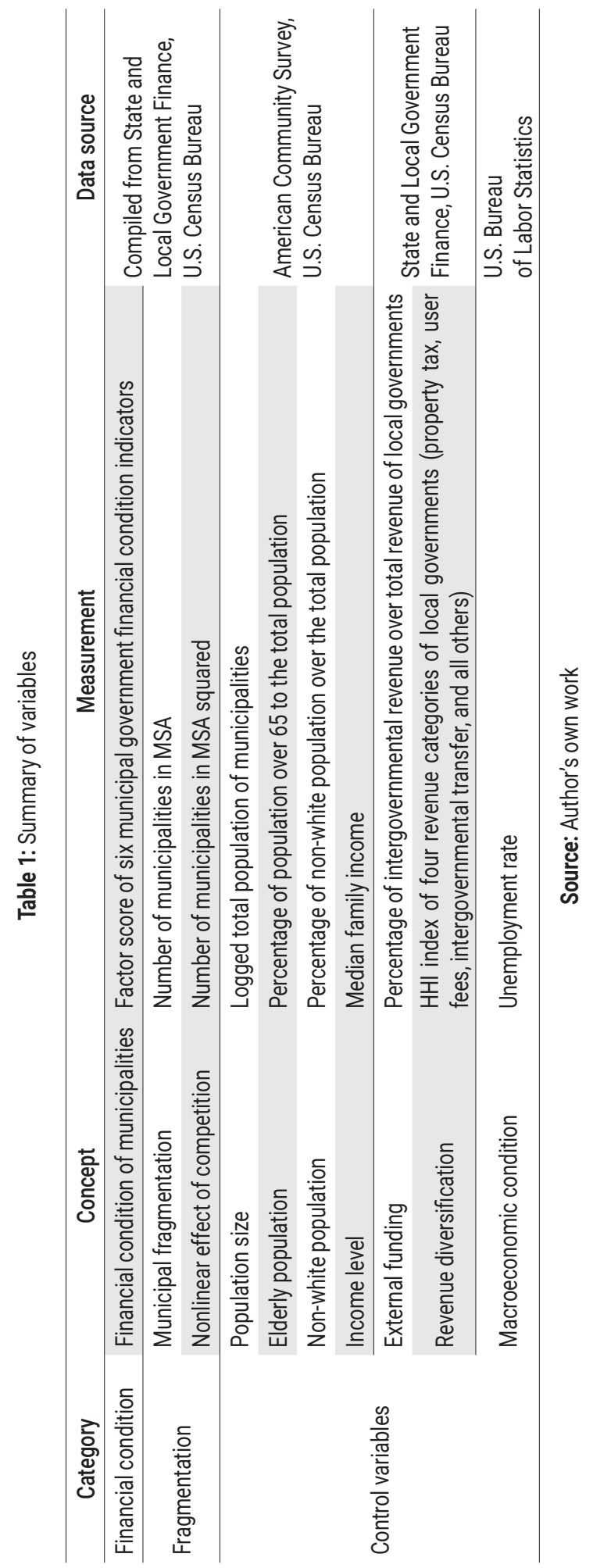


Table 3: Regression results for municipality financial condition

\begin{tabular}{|c|c|c|}
\hline Variables & (1) & (2) \\
\hline \multirow[t]{2}{*}{ No. of municipalities } & $-0.228 * \star \star$ & -0.336 *** \\
\hline & $(0.0389)$ & $(0.0652)$ \\
\hline \multirow[t]{2}{*}{ No. of municipalities squared } & & $0.00329 * \star \star$ \\
\hline & & $(0.00125)$ \\
\hline \multirow[t]{2}{*}{ Population, logged } & -0.00527 & -0.00353 \\
\hline & $(0.00498)$ & $(0.00501)$ \\
\hline \multirow[t]{2}{*}{ Population over 65} & $-1.705^{\star \star \star}$ & $-1.698 * \star \star$ \\
\hline & $(0.508)$ & $(0.507)$ \\
\hline \multirow[t]{2}{*}{ Non-white population } & 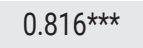 & $0.815^{\star \star \star}$ \\
\hline & $(0.226)$ & $(0.226)$ \\
\hline \multirow[t]{2}{*}{ Median family income } & $3.21 \mathrm{e}-07$ & $2.78 \mathrm{e}-07$ \\
\hline & $(7.62 \mathrm{e}-07)$ & $(7.61 e-07)$ \\
\hline \multirow[t]{2}{*}{ Intergovernmental revenue } & $-0.503^{\star \star \star}$ & $-0.505^{\star \star \star}$ \\
\hline & $(0.102)$ & $(0.102)$ \\
\hline \multirow[t]{2}{*}{ Revenue diversification } & $0.890 * \star \star$ & $0.892^{\star * *}$ \\
\hline & $(0.139)$ & $(0.139)$ \\
\hline \multirow[t]{2}{*}{ Unemployment rate } & $-2.044^{\star \star *}$ & $-2.066 * \star \star *$ \\
\hline & $(0.591)$ & $(0.591)$ \\
\hline \multirow[t]{2}{*}{ Constant } & $1.481 * \star \star$ & $2.034 * \star \star$ \\
\hline & $(0.251)$ & $(0.367)$ \\
\hline Observations & 3,480 & 3,480 \\
\hline R-squared & 0.877 & 0.878 \\
\hline Number of MSAs & 348 & 348 \\
\hline \multirow[t]{2}{*}{ Wald $\mathrm{Chi}^{2}$} & 31899.73 & 31985.93 \\
\hline & $(0.000)$ & $(0.000)$ \\
\hline
\end{tabular}

Note: Standard errors in parentheses ${ }^{* *} p<0.01, * * p<0.05,{ }^{*} p<0.1$; Coefficients of individual MSA dummy variables are not included.

Source: Author's own work

diversification have positive effects, while the elderly population and unemployment rate have negative effects on the municipal financial condition. However, the population size of municipalities and median income levels do not have a significant influence on the financial condition. The elderly population and the unemployment rate have the most substantial effects, implying that the population associated with specific welfare services with less economic activity and the macroeconomic condition are critical factors. In both models, the independent variables explain above $87 \%$ of variance of the financial condition.

Figure 1 exhibits the estimated variation of the municipal financial condition in 95 percent confidence interval based on the fully specified model (2). In spite of the broadening confidence interval at some points, the estimated financial condition consistently decreases when the municipal fragmentation increases. Given the national 


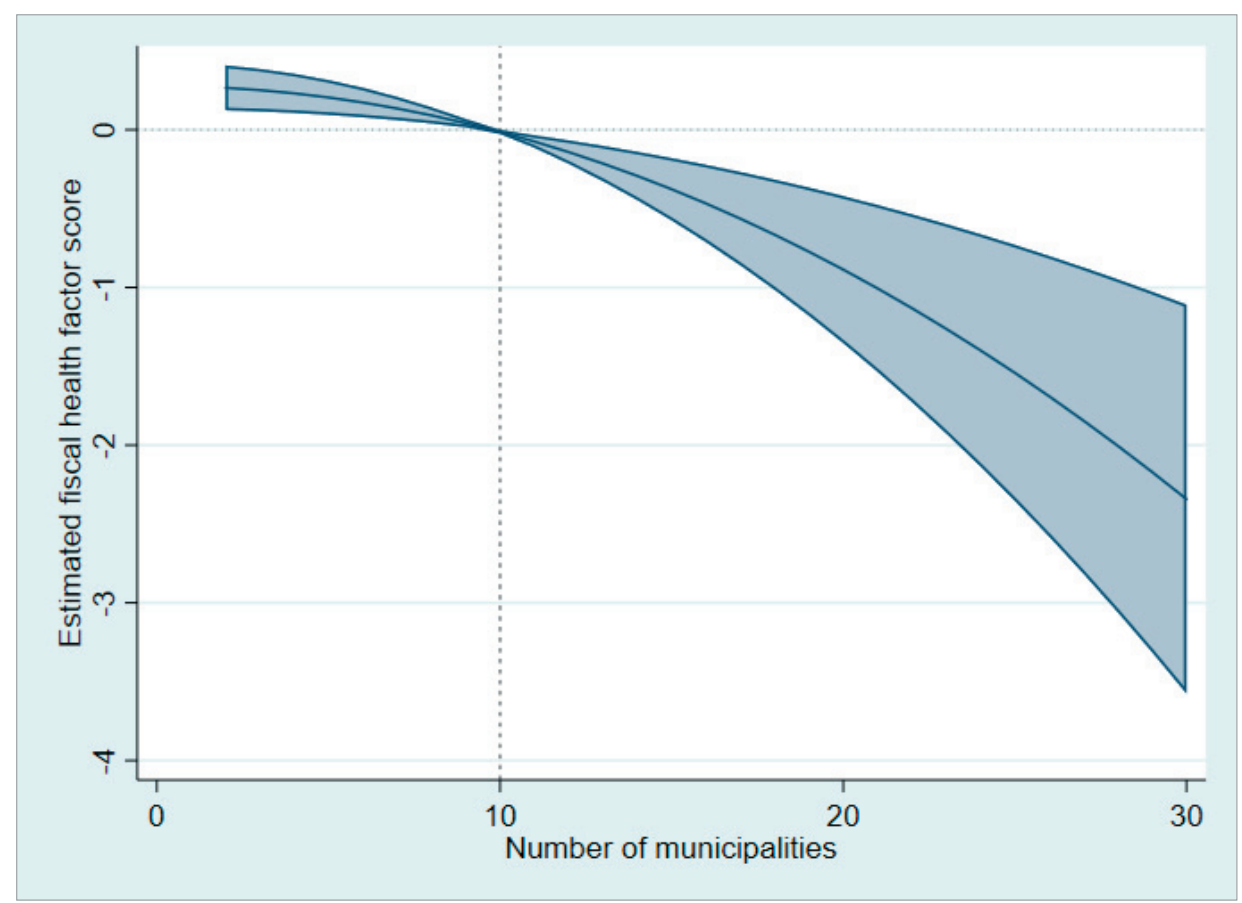

Note: The shaded areas represent 95 percent confidence interval.

Figure 1: Estimated marginal effects of municipal fragmentation on financial condition

Source: Author's own work

average of financial condition score with zero, on average, an MSA with ten or more municipal governments tend to have lower financial condition than the rest.

\section{Conclusion}

This study aims to test the effects of municipal fragmentation on their financial condition, the ability to meet financial and service obligations for citizens. It is hypothesized that fragmentation declines municipalities' financial condition, excessive intergovernmental competition, no replacement for the fiscally unhealthy municipalities, and higher cost of coordinating several service providers. To identify changes in the financial condition, this study develops a measure of financial condition based on the factor analysis of six fiscal indicators of local governments reported between 1972 and 2017 at the MSA level. The regression using panel-corrected standard errors supports the hypotheses. The findings provide evidence of defective municipality fragmentation, of which efficiency enhancement documented by the existing literature is outweighed by the financial condition.

The findings suggest reducing the number of municipalities, as the greater number of municipalities declines their financial condition. Consolidating and merging the multi-purpose governments are understood as costly decisions, and they are often 
ineffective in achieving efficiency and economic development, entailing conflicts among political stakeholders (Leland and Thurmaier, 2005). However, the outcomes beyond a single dimension of government efficiency from the existing studies tend to focus on efficiency and economic development, while other financial and service capacities of local government remain overlooked. The findings of this study imply that fewer municipalities may increase their responsiveness to provide demanded services and preserve fiscal capacity, supporting the institutional reform perspective, that avoids higher transaction costs and citizen confusion that result from local fragmentation.

This study has some limitations that can be addressed in future studies. First, this study does not test the effects of fragmentation outside MSAs. MSA is a unit of analysis used in this study to investigate the interaction among governments in a market of public goods and services where citizen-customers shop across the vendor jurisdictions. The unit of analysis excludes municipalities in sparsely populated areas associated with relatively lower financial condition as well as lower service demands. There may be different patterns of fragmentation identified by financial condition. Second, this study utilizes factor analysis to compile several indicators of financial condition into one. The measure is useful to understand the overall pattern of the financial condition of municipalities, but it does not provide which indicator specifically varies. Nevertheless, diagnosing the effect of fragmentation on the individual financial condition indicators does not capture the multifaceted concept of financial condition, nor does it capture the idea of diverse fiscal outcomes such as government efficiency, urban sprawl, income segregation. Third, the indicators for financial condition score omit some important information on the accounting bases. For example, fund balance as a slack resource is a crucial indicator of financial condition because it allows continuous service provision during economically hard times (Hendrick, 2011). However, the indicator is not included in this study as the accounting information is available at Comprehensive Annual Financial Reports, which are not available over several years corresponding to all municipalities in the sample of this study. Last, this study focuses on the relationship among municipalities only. Recent trends in proliferation of special districts demonstrates that municipal governments heavily rely on the single-purpose governments with flexible boundaries (Park and Shi, 2021). The municipal governments may have little incentive to compete each other directly, but the special districts could potentially differentiate the variety of services (Park and Park, 2021). However, a few studies investigate whether and how the special district enhances or declines the fiscal condition of municipalities. 


\section{References:}

1. Advisory Commission on Intergovernmental Relations (ACIR), Interjurisdictional Tax and Policy Competition: Good or Bad for the Federal System? (M-177), Washington, DC: U.S. Advisory Commission on Intergovernmental Relations, 1991.

2. Advisory Commission on Intergovernmental Relations (ACIR), The Tension of Interdependence (M-89), Washington, DC: U.S. Advisory Commission on Intergovernmental Relations, 1974.

3. Alesina, A., Baqir, R. and Hoxby, C., 'Political Jurisdictions in Heterogeneous Communities', 2004, fournal of Political Economy, vol. 112, no. 2, pp. 348-396.

4. Badu, Y.A. and Li, S.Y., 'Fiscal Stress in Local Government: A Case Study of the Tri-Cities in the Commonwealth of Virginia', 1994, The Review of Black Political Economy, vol. 22, no. 3, pp. 5-17.

5. Bailey, M.A., Rom, M.C. and Taylor, M.M., 'State Competition in Higher Education: A Race to the Top, or a Race to the Bottom?', 2004, Economics of Governance, vol. 5, no. 1, pp. 53-75.

6. Beck, N. and Katz, J.N., 'What to Do (and Not to Do) with Time-Series Cross-Section Data', 1995, American Political Science Review, vol. 89, no. 3, pp. 634-647.

7. Berne, R., The Relationships between Financial Reporting and the Measurement of Financial Condition, Government Accounting Standard Board, Research Report No. 18, Norwalk, CT, 1992.

8. Besley, T. and Case, A., 'Does Electoral Accountability Affect Economic Policy Choices? Evidence from Gubernatorial Term Limits', 1995, The Quarterly fournal of Economics, vol. 110, no. 3, pp. 769-798.

9. Boyne, G.A., 'Local Government Structure and Performance: Lessons from America?', 1992, Public Administration, vol. 70, no. 3, pp. 333-357.

10. Boyne, G.A., 'Scale, Performance and the New Public Management: An Empirical Analysis of Local Authority Services', 1996, Journal of Management Studies, vol. 33, no. 6, pp. 809-826.

11. Brennan, G. and Buchanan, J.M., The Power to Tax: Analytic Foundations of a Fiscal Constitution, Cambridge University Press, 1980.

12. Breton, A., 'The Existence and Stability of Interjurisdictional Competition', in Kenyon, D.A. and Kincaid, J. (eds.), Competition among States and Local Governments: Efficiency and Equity in American Federalism, Washington DC: The Urban Institute Press, 1991, pp. 37-56.

13. Brown, K.W., 'The 10-Point Test of Financial Condition: Toward an Easy-to-Use Assessment Tool for Smaller Cities', 1993, Government Finance Review, vol. 9, pp. 21-21.

14. Carr, J.B. and Hawkins, C.V., 'The Costs of Cooperation: What the Research Tells Us About Managing the Risks of Service Collaborations in the US', 2013, State and Local Government Review, vol. 45, no. 4, pp. 224-239.

15. Carroll, D.A. and Goodman, C.B., 'Understanding and Measuring Revenue Elasticity, Volatility, and Implications for Local Government Fiscal Health', in Levine, H., Justice, J.B. and Scorsone, E.A. (eds.), Handbook of Local Government Fiscal Health, Burlington, MA: Jones \& Bartlett Learning, 2013, pp. 225-252. 
16. Carruthers, J.I. and Ulfarsson, G.F., 'Fragmentation and Sprawl: Evidence from Interregional Analysis', 2002, Growth and Change, vol. 33, no. 3, pp. 312-340.

17. Chernick, H. and Reschovsky, A., 'Lost in the Balance: How State Policies Affect the Fiscal Health of Cities', La Follette Working Papers, Madison, WI: University of Wisconsin, 2001.

18. Clark, B.Y., 'Evaluating the Validity and Reliability of the Financial Condition Index for Local Governments', 2015, Public Budgeting \& Finance, vol. 35, no. 2, pp. 66-88.

19. Dowding, K. and Mergoupis, T., 'Fragmentation, Fiscal Mobility, and Efficiency', 2003, The Journal of Politics, vol. 65, no. 4, pp. 1190-1207.

20. Eberts, R.W. and Gronberg, T.J., 'Can Competition among Local Governments Constrain Government Spending?', 1988, Economic Review, vol. 24, no. 1, pp. 2-9.

21. Feiock, R.C. and Scholz, J.T., Self-Organizing Federalism: Collaborative Mechanisms to Mitigate Institutional Collective Action Dilemmas, Cambridge University Press, 2009.

22. Feiock, R.C., Lee, I.W., Park, H.J. and Lee, K.H., 'Collaboration Networks among Local Elected Officials: Information, Commitment, and Risk Aversion', 2010, Urban Affairs Review, vol. 46, no. 2, pp. 241-262.

23. Fischel, D.R., 'Race to the Bottom Revisited: Reflections on Recent Developments in Delaware's Corporation Law', 1981, Northwestern University Law Review, vol. 76, no. 6, pp. 913-945.

24. Gist, J.R., 'Economic Recession and the Fiscal Conditions of City Governments', 1988, Journal of Urban Affairs, vol. 10, no. 3, pp. 253-272.

25. Gold, S.D., The Fiscal Crisis of the States: Lessons for the Future, Georgetown University Press, 1995.

26. Goodman, C.B., 'Local Government Fragmentation: What Do We Know?', 2019, State and Local Government Review, vol. 51, no. 2, pp. 134-144.

27. Gorina, E., Maher, C. and Joffe, M., 'Local Fiscal Distress: Measurement and Prediction', 2018, Public Budgeting \& Finance, vol. 38. no. 1, pp. 72-94.

28. Governmental Accounting Standards Board (GASB), 'The User's Perspective', 2009, [Online] available at https://www.gasb.org/newsletter/fiscal_sustainability_dec2009.html, accessed on September 1, 2021.

29. Grossman, G., Pierskalla, J.H. and Boswell Dean, E., 'Government Fragmentation and Public Goods Provision’, 2017, The fournal of Politics, vol. 79, no. 3, pp. 823-840.

30. Groves, S.M., Nollenberger, K. and Valente, M.G., Evaluating Financial Condition: A Handbook for Local Government, ICMA, 2003.

31. Hendrick, R., 'Assessing and Measuring the Fiscal Heath of Local Governments: Focus on Chicago Suburban Municipalities', 2004, Urban Affairs Review, vol. 40, no. 1, pp. 78-114.

32. Hendrick, R.M., Jimenez, B.S. and Lal, K., 'Does Local Government Fragmentation Reduce Local Spending?', 2011, Urban Affairs Review, vol. 47, no. 4, pp. 467-510.

33. Hendrick, R.M., Managing the Fiscal Metropolis: The Financial Policies, Practices, and Health of Suburban Municipalities, Georgetown University Press, 2011.

34. Hill, R.C., 'Separate and Unequal: Governmental Inequality in the Metropolis', 1974, American Political Science Review, vol. 68, no. 4, pp. 1557-1568.

35. Honadle, B.W., 'Local Government Fiscal Health: An Intergovernmental Perspective', in Levine, H., Justice, J.B. and Scorsone, E.A. (eds.), Handbook of Local Government Fiscal Health, Burlington, MA: Jones \& Bartlett Learning, 2013, pp. 367-387. 
36. Hoyt, W.H., 'Property Taxation, Nash Equilibrium, and Market Power', 1991, fournal of Urban Economics, vol. 30, no. 1, pp. 123-131.

37. Jacob, B. and Hendrick, R., 'Assessing the Financial Condition of Local Governments', in Levine, H., Justice, J.B. and Scorsone, E.A. (eds.), Handbook of Local Government Fiscal Health, Burlington, MA: Jones \& Bartlett Learning, 2013, pp. 11-40.

38. Justice, J.B. and Scorsone, E.A., 'Measuring and Predicting Local Government Fiscal Stress', in Levine, H., Justice, J.B. and Scorsone, E.A. (eds.), Handbook of Local Government Fiscal Health, Burlington, MA: Jones \& Bartlett Learning, 2013, pp. 43-74.

39. Krueger, S. and Walker, R.W., 'Management Practices and State Bond Ratings', 2010, Public Budgeting \& Finance, vol. 30, no. 4, pp. 47-70.

40. Ladd, H.F. and Yinger, J.M., America's Ailing Cities: Fiscal Health and the Design of Urban Policy, Baltimore: Johns Hopkins University Press, 1989.

41. Leland, S. and Thurmaier, K., 'When Efficiency Is Unbelievable: Normative Lessons from 30 Years of City-County Consolidations', 2005, Public Administration Review, vol. 65, no. 4, pp. $475-489$.

42. Lowery, D., 'A Transactions Costs Model of Metropolitan Governance: Allocation versus Redistribution in Urban America', 2000, fournal of Public Administration Research and Theory, vol. 10, no. 1, pp. 49-78.

43. Lyons, W.E., Lowery, D. and DeHoog, R.H., The Politics of Dissatisfaction: Citizens, Services, and Urban Institutions, M.E. Sharpe, 1992.

44. Maher, C.S. and Deller, S.C., 'Measuring Municipal Fiscal Condition: Do Objective Measures of Fiscal Health Relate to Subjective Measures?', 2011, fournal of Public Budgeting, Accounting \& Financial Management, vol. 23, no. 3, pp. 455-478.

45. McGranahan, L., 'State Budgets and the Business Cycle: Implications for the Federal Balanced Budget Amendment Debate', 1999, Economic Perspectives, vol. 23, no. 3, pp. 2-17.

46. McGuire, T.J., 'Federal Aid to States and Localities and the Appropriate Competitive Framework', in Kenyon, D.A. and Kincaid, J. (eds.), Competition among States and Local Governments: Efficiency and Equity in American Federalism, Washington DC: The Urban Institute Press, 1991, pp. 153-164.

47. Morgan, D.R. and Mareschal, P., 'Central-City/Suburban Inequality and Metropolitan Political Fragmentation', 1999, Urban Affairs Review, vol. 34, no. 4, pp. 578-595.

48. Niskanen, W., Bureaucracy and Representative Democracy, Chicago \& New York: AldineAtherton, 1971.

49. Oakerson, R.J., Governing Local Public Economies: Creating the Civic Metropolis, Oakland, CA: ICS Press, 1999.

50. Oates, W., Fiscal Federalism, Harcourt Brace Jovanovich, 1972.

51. Olkin, R., What Psychotherapists Should Know about Disability, New York: Guilford Press, 2001.

52. Ostrom, V. and Ostrom, E., 'A Behavioral Approach to the Study of Intergovernmental Relations', 1965, The ANNALS of the American Academy of Political and Social Science, vol. 359, no. 1, pp. 137-146.

53. Panzar, J.C. and Willig, R.D., 'Economies of Scope', 1981, The American Economic Review, vol. 71 , no. 2, pp. 268-272. 
54. Park, H. and Park, H.J., 'Outsourcing Services: A Theory of Special District Incorporation', 2021, Public Performance \& Management Review, published online, DOI: 10.1080/15309576.2021.1972430.

55. Park, H. and Shi, Y., 'District Reliance by Service Function: A Study of Public Financing of American Special Districts', 2021, Journal of Public and Nonprofit Affairs, vol. 7, no. 1, pp. $10-28$.

56. Park, S.M. and Rainey, H.G., 'Leadership and Public Service Motivation in US Federal Agencies', 2008, International Public Management fournal, vol. 11, no. 1, pp. 109-142.

57. Peters, G., 'Fiscal Strains on Welfare State: Causes and Consequences', in Levine, C.H. and Rubin, I. (eds.), Fiscal Stress and Public Policy, Beverly Hills: Sage Publication, 1980, pp. 23-48.

58. Schneider, M., 'Intermunicipal Competition, Budget-Maximizing Bureaucrats, and the Level of Suburban Competition', 1989, American fournal of Political Science, vol. 33, no. 3, pp. 612-628.

59. Shamsub, H. and Akoto, J.B., 'State and Local Fiscal Structures and Fiscal Stress', 2004, Journal of Public Budgeting, Accounting \& Financial Management, vol. 16, no. 1, pp. 40-61.

60. Suyderhoud, J.P., 'State-Local Revenue Diversification, Balance, and Fiscal Performance', 1994, Public Finance Quarterly, vol. 22, no. 2, pp. 168-194.

61. Tiebout, C.M., 'A Pure Theory of Local Expenditures', 1956, fournal of Political Economy, vol. 64, no. 5, pp. 416-424.

62. Volden, C., 'The Politics of Competitive Federalism: A Race to the Bottom in Welfare Benefits?', 2002, American fournal of Political Science, vol. 46, no. 2, pp. 352-363.

63. Wildasin, D.E., 'Interjurisdictional Capital Mobility: Fiscal Externality and a Corrective Subsidy', 1989, Journal of Urban Economics, vol. 25, no. 2, pp. 193-212.

64. Williamson, O.E., 'Transaction Cost Economics: The Comparative Contracting Perspective', 1987, fournal of Economic Behavior \& Organization, vol. 8, no. 4, pp. 617-625.

65. Wooldridge, J. M., Introductory Econometrics: A Modern Approach, Boston: Cengage Learning, 2012. 


\section{Appendix}

Table A-1 lists the direct indicators prepared to generate a measure of financial condition. The 6-indicators sample overlap with 12-indicator samples that have 6 additional indicators. The 6 other indicators that are not commonly identified in both samples have some issues in facial validity and correlation with other indicators. For example, tax revenue and revenues from fees and charges are subordinated to the own-source revenue, while intergovernmental revenue is the total revenue minus own-source revenue. Debt service includes both interests and repaid principals, which are derivatives of long-term debt outstanding. Similarly, retirement expenditure reflects a subset of operating expenditure. In each sample every 5 years, the factor analyses are implemented. This section evaluates which sample better represents the concept (or latent construct) of local financial condition.

Table A-1: List of financial condition indicators

\begin{tabular}{lll}
\hline & 12 indicators & \multicolumn{1}{c}{6 indicators } \\
\hline Budget surplus/deficit & Expenditure on retirement & Budget surplus/deficit \\
Capital expenditure & Revenues from fees and charges & Capital expenditure \\
Cash and security holding & Intergovernmental revenue & Cash and security holding \\
Current operating expenditure & Long-term debt outstanding & Current operating expenditure \\
Debt service & Own-source revenue & Long-term debt outstanding \\
Tax revenue & Total revenue per capita & Own-source revenue \\
\hline
\end{tabular}

Source: Author's own work

The Kaiser-Myer-Olkin test of sampling adequacy value close to one indicates the observed indicators commonly share one or more latent variables. The value close to zero means only partial correlations in a few pairs of indicators exist. An acceptable threshold of Kaiser-Meyer-Olkin value is 0.6 or above, signifying a sample is appropriate for factor analysis.

Both samples, built on 12 indicators and 6 indicators, satisfy the thresholds, but the 6 indicators are better measures for conducting factor analysis to measure financial condition than the twelve indicators. The six indicators provide sufficient variance to identify the underlying concept of financial condition with fewer indicators.

Table A-2: Kaiser-Meyer-Olkin test of sampling adequacy by sample

\begin{tabular}{ccccccc}
\cline { 1 - 2 } \cline { 5 - 6 } Year & 6 indicators & 12 indicators & & Year & 6 indicators & 12 indicators \\
\hline 1972 & 0.699 & 0.562 & & 1997 & 0.775 & 0.551 \\
1977 & 0.793 & 0.580 & & 2002 & 0.740 & 0.567 \\
1982 & 0.734 & 0.609 & & 2007 & 0.737 & 0.545 \\
1987 & 0.756 & 0.583 & & 2012 & 0.728 & 0.559 \\
1992 & 0.730 & 0.531 & & 2017 & 0.775 & 0.527 \\
\hline
\end{tabular}

Source: Author's own work 
The financial condition factors from the six indicators are stronger as the variance differences between the first and the second potential factor are larger than the twelve-indicator samples, whereas the twelve-indicator samples leave some possibility that multiple substantial factors that constitute financial condition may exist.

Table A-3: Total variance of municipality indicators explained by possible factors

\begin{tabular}{ccccc}
\hline \multirow{2}{*}{ Year } & \multicolumn{2}{c}{6 indicators } & \multicolumn{2}{c}{12 indicators } \\
\cline { 2 - 5 } & First factor & Second factor & First factor & Second factor \\
\hline 1972 & $68.15 \%$ & $17.12 \%$ & $46.27 \%$ & $16.94 \%$ \\
\hline 1977 & $68.76 \%$ & $16.55 \%$ & $48.35 \%$ & $15.25 \%$ \\
\hline 1982 & $66.01 \%$ & $17.56 \%$ & $48.81 \%$ & $13.50 \%$ \\
\hline 1987 & $67.15 \%$ & $17.78 \%$ & $49.60 \%$ & $13.35 \%$ \\
\hline 1992 & $64.52 \%$ & $18.31 \%$ & $45.67 \%$ & $13.79 \%$ \\
\hline 1997 & $67.52 \%$ & $17.88 \%$ & $46.92 \%$ & $14.23 \%$ \\
\hline 2002 & $66.56 \%$ & $16.46 \%$ & $44.85 \%$ & $15.01 \%$ \\
\hline 2007 & $63.64 \%$ & $18.27 \%$ & $43.70 \%$ & $12.19 \%$ \\
\hline 2012 & $65.43 \%$ & $18.60 \%$ & $45.04 \%$ & $12.31 \%$ \\
\hline 2017 & $67.21 \%$ & $16.02 \%$ & $44.56 \%$ & $12.56 \%$ \\
\hline
\end{tabular}

Source: Author's own work 